\title{
DROUGHT SPELLS AND THEIR IMPACT ON THE GROWTH OF YOUNG PLANTATIONS ESTABLISHED WITH THE CONTAINERIZED PLANTING STOCK
}

\author{
Oldřich Mauer ${ }^{1}$, Martin Rozmánek ${ }^{1}$, Kateřina Houšková ${ }^{1}$ \\ ${ }^{1}$ Department of Silviculture, Faculty of Forestry and Wood Technology, Mendel University in Brno, Zemědělská 3, \\ 61300 Brno, Czech Republic
}

\begin{abstract}
MAUER OLDŘICH, ROZMÁNEK MARTIN, HOUŠKOVÁ KATEŘINA. 2018. Drought Spells and Their Impact on the Growth of Young Plantations Established with the Containerized Planting Stock. Acta Universitatis Agriculturae et Silviculturae Mendelianae Brunensis, 66(1): 0089-0099.

In 2013-2016, the growth and post-planting losses were monitored of bare-rooted and containerized planting stock of European beech, Norway spruce and Douglas fir together with the course of weather in seven regions of the Czech Republic, most endangered by drought. Precipitation deficits occurred especially in the spring period of 2015 and in the summer period of 2016, significant drought spells being recorded also in the summer periods of years 2013 and 2015. If there is a normal weather after planting, the containerized planting stock exhibits better growth. If the planting is followed by severe spells of drought, both the bare-rooted and the containerized planting stock dies, the containerized planting stock more so. The containerized planting stock responds worse to repeated drought spells. Drought spells are at all times better endured by the containerized planting stock with the large root balls, root ball coverage and strong root collar. Coverage of clear-cut areas is significantly affected by the success of regeneration, which depends on the used type of planting stock, as well as by the spells of drought. Good growth in the first year after planting does not guarantee the success of regeneration, particularly if the containerized planting stock is concerned.
\end{abstract}

Keywords: drought, containerized planting stock, bare-rooted planting stock, mortality, morphological parameters

\section{INTRODUCTION}

Although the method of using containerized planting stock in forest regeneration is on principle very old, the first written references dating back to the $16^{\text {th }}$ century, it started to be used more as late as since the 1960s (Poleno, Vacek et al., 2009). After certain stagnations (e.g. in the 1980s in the countries of northern Europe or in the Czech Republic towards the end of the last century), the method finds increasing applications. For example, the use of containerized planting stock reaches over $90 \%$ in the countries of northern Europe, and in the Czech Republic, its use in forest regeneration is currently higher than $30 \%$ and it is expected to grow to over 50\% (Mauer et al., 2009).
All authors describing pros and cons of the containerized planting stock (e.g. Dušek 1997; Šmelková et al., 2001; Szabla, Pabian 2009; Jurásek, Martincová, Nárovcová 2004) agree upon its main biological advantages, which are as follows:

- Forests can be regenerated throughout the year with exceptions when the ground is frozen or muddy or in the period of intensive annual increment;

- Containerized planting stock does not suffer of post-planting shock, its growth and gain are better, and the young plantation is established earlier; 
- Containerized planting stock suffers less mechanical damage at handling and planting and is more resistant to drying out.

As the main biological disadvantage, the same authors state possible root system malformations induced particularly by inadequate technology of raising the planting stock. With no factual evidence, nearly none of these authors recommends planting of containerized stock in the periods of severe drought. Dušek (1997) and Šmelková et al. (2001) directly do not advise to plant the stock in containers to be grown through by roots on the dry sites because on such sites, the containers would not become decomposed in the soil, thus hampering the growth of roots from the root ball. However, there is no exact information in the available literature, which would compare the growth of bare-rooted and containerized planting stock on the same site in relation to drought periods.

Although the weather change has been discussed as an urgent issue only recently, foresters have been recording the changes already several tens of years, having been responding gradually and more or less with empirical success by changing the size and type of planting stock used in forest regeneration. The planting stock used is ever younger, with a larger root system and a smaller assimilation apparatus (Mauer, Palátová 2006). Changing are also methods of protecting the planted stock in the first years after planting, which are to prevent massive loss of moisture from the soil or from the assimilatory tissue. Published were also some partial data on raising planting stock resistant to drought stress (Mauer, Vaněk 2013). It was also found out that the main influence on the drought resistance of planting stock is that of its origin or the mean total precipitation in the growing season at the place of origin of the plant (Bolte et al., 2016). Current spells of drought are so intensive and long lasting that losses in forest regeneration often exceed $70 \%$. Unfortunately, the only measure of the forestry practice is inhibition or stoppage of regeneration and reforestation.

Specialized workplaces recorded the long-term weather course change, too. For example, Rožnovský, Bauer (2006) or Bagar, Nekovár (2006) admit that some regions feature a shift by up to two forest altitudinal vegetation zones due to weather change as compared with 1960 (forest typology however does not want to respond to the change reasoning that no change in soil properties occurred). Although some politicians and other personalities cast doubts on the change of weather course (climate change), experts warn that problems might be even more serious. According to various scenarios, mean air temperature may increase by up to $6{ }^{\circ} \mathrm{C}$, and even though the scenarios often do not presume a radical change in total precipitation amounts, they keep warning that rains will be often torrential and alternating with long spells of drought (CHMI 2017; Jouklová, 2016).

The recent course of weather causes serious problems in forest regeneration. Severe drought spells during the growing season and namely in the spring period result in enormous post-planting losses. One of possible solutions appears a wider use of containerized plantings stock. The aim of the study was to verify exactly the growth of young plantations established with the bare-rooted and containerized planting stock of our main tree species in the most threatened areas of the Czech Republic, i.e. at mid-(400-600 $\mathrm{m}$ a.s.l.) and lower (under 400 m a.s.l.) elevations.

\section{MATERIAL AND METHODS}

In 2013, 2014, 2015 and 2016, research plots were established in the main groups of forest type (GFT) at mid-and lower elevations of the Czech Republic (according to Plíva 1991; Viewegh et al., 2003):

- $2 \mathrm{~K}$ (Acidic Beech-Oak),

- 2S (Nutrient-medium Beech-Oak),

- 3M (Nutrient-very poor Oak-Beech),

- 3K (Acidic Oak-Beech),

- 3S (Nutrient-medium Oak-Beech),

- 4K (Acidic Beech),

- 4S (Nutrient-medium Beech).

All these plots are situated in the surroundings of towns Jedovnice, Boskovice and Prostějov. All plots were established on clear-cut areas sized 0.30-0.60 ha, with all clear-cut areas being sheltered on three sides at minimum by stands whose minimum height was $8 \mathrm{~m}$. Each clear-cut area (in each year) was planted with the bare-rooted transplants of:

- European beech (BK) 1-1 (2 year old plants undercut after 1 years of culture),

- Douglas fir (DG) $1+2$ (3 year old plants transplanted after 1 years of culture),

- Norway spruce (SM) 2+2 (4 year old plants transplanted after 2 years of culture)

together with the containerized seedlings and transplants of:

- BK fvl (1 year old seedlings cultured by aircutting in a greenhouse),

- SM fv0.5 + v1.5 (2 year old plants cultured by aircutting for half a year in a greenhouse and then in the open air transplanted into bigger containers),

- DG fv0.5 + v1.5 (2 year old plants cultured by aircutting for half a year in a greenhouse and then in the open air transplanted into bigger containers).

With the exception of year 2013, when the containerized stock was planted in the autumn of 2012 and the bare-rooted stock in the spring of 2013, in all the other years, both the bare-rooted and the containerized stocks were planted in the spring period (April) of the given year of planting. (For objective reasons-the lack of high-quality planting stock-not all stock was planted out on all plots each year.) Both the bare-rooted stock and the containerized stock were planted by hole planting. The planting stock was not heeled in before planting; to the planting 
site, the bare-rooted stock was transported in plastic bags and the containerized stock in the shrink-wrap. Most research plots were fenced and the young plantations were given standard care (protection against weeds by mowing, weevil control by spraying, and protection against browsing in unfenced areas by repellents).

The containerized beech seedlings were raised in HIKO V-265 containers. The containerized plants of Norway spruce and Douglas fir were raised in HIKO $\mathrm{V}-350$ containers. All planting stock was raised in a forest nursery nearby the site on which the research plots were established (altitude $400 \mathrm{~m}$ a.s.l.). Exception was the additional testing of container size influence on post-planting losses in the spring of 2015, when HIKO V125, HIKO V-265 and HIKO $\mathrm{V}-350$ containers were used for raising BK fvl.

Parameters and features ascertained in 100 pcs of each planted tree species and each planting stock type on each research plot at the end of each growing season were as follows (schematically chosen rows were used for the assessment): above-ground part height, last terminal increment, root collar diameter, last length of branch increment, crown width and shape, stem form, height of the setting of multiple stems, size and colour of assimilation apparatus, and damage by biotic and abiotic agents. Losses were recorded in all plants at the end of each growing season and during each spring period. In the results of this work, however, only two decisive parameters are presented, i.e. post-planting losses and terminal increments.

Since we tested climax tree species, the size and shape of chosen clear-cut areas reflected the fact. Plantations were established in 2015 on clear-cut areas sized up to 0.2 ha (GFT $3 \mathrm{~S}$ and $4 \mathrm{~K}$ ), sheltered from all sides by the adult stand, and on a large (ca 4.0 ha), open and unsheltered clear-cut area after a wind-throw disaster, with the aim to find out how the clear-cut size and sheltering would affect the results.

In 2017, a test was established to identify the rate of water loss from root balls of diverse sizes in dependence on physical soil properties, drought duration and root ball coverage or non-coverage after planting. This research plot was completely without weeds (chemical elimination) and its design was identical as that of the other plots. The planting took place on groups of forest types 4K-lighter soils and 4G (Wet Oak-Fir according to Viewegh et al., 2003)-heavier soils. Container types used for the spring planting were HIKO V-265 and HIKO V-350; hole planting with the coverage and without the coverage of root balls was used to plant only the root balls without the plants. Drought spells were simulated by covering the planted root balls with the transparent PE foil at a height of 60-80 $\mathrm{cm}$ above the soil surface. The root balls were fully saturated with water at the time of planting. The loss of their weight (water loss) was ascertained by the representative method on Day 10, 15, 20 and 30 after planting.
The quality of planting stock used was assessed prior to each planting. All planting stock complied with the Czech standard ČSN 48 2115; however, there were differences between the bare-rooted and containerized planting stocks. The containerized stock had a smaller diameter of root collar and a smaller shoot length. (The differences were particularly vast in European beech and Douglas fir in 2016.) For us to be able to ascertain the effect of using the plants of different height and the plants of the same height with different root collar diameters, we planted the BK fvl of identical height with different root collar diameters (beech seedlings were raised in HIKO V-265 containers) and the BK fvl raised in containers of different sizes (HIKO V-120, HIKO V-265, HIKO V-350) on GFT $3 \mathrm{~K}$ and $4 \mathrm{~K}$ in the spring period of 2015 . The seedlings were of not only different shoot length, different root collar diameter but also featured different root ball sizes at the time of planting.

To monitor exact weather course, three meteorological stations were chosen together with experts from ČHMÚ (Czech Hydrometeorological Institute) delineating the area of the established research plots, from which relevant data were taken over: Brno-Tuřany, Olomouc and Březová nad Svitavou. Measurements of these stations (since 1960) were complemented with data from three hydrometeorological stations inside the studied region-Prostějov, Cetkovice and Konice. Data from the hydrometeorological stations in Brno-Turany, Olomouc, Cetkovice and partly from Prostějov are available on the internet (portal.chmi.cz, www. cetkovice.cz, www.in-pocasi.cz); data from the other stations were provided on a commercial base.

Results were processed using standard statistical methods. Significance of differences between the parameters of bare-rooted and containerized planting stock of the same tree species on the same plot was ascertained by the T-test at a significance level of 0.05 after verification of the assumptions for the use of parametric tests. The correct type of T-test (for the equal or unequal variance) was assessed on the base of F-test. In the table of results, the exactly measured parameters are expressed as fractional numbers with arithmetic mean and standard deviation in numerator and denominator, respectively. Signs behind the fraction (+ significant difference, - non-significant difference) express the statistically significant difference between the data sets.

\section{RESULTS}

\section{Weather course in the period from 2013-2016}

The analysis of data from the six hydrometeorological stations showed that severe spells of drought occurred in the region where the research plots had been established in the spring of 2015 and in the summer of 2016; significant drought spells occurred in the summer periods 
of years 2013 and 2015, too. The precipitation deficit amounted up to $50 \%$ of long-term average; the precipitation was often of torrential rain character, the number of days without precipitation increased, Lang's rain factor significantly decreased and the average daily temperature increased. Although a detailed weather course might slightly differ on the individual research plots, the data definitely characterize the course of weather in the area of established research plots.

\section{Assessment of plantations in the period from 2013-2016}

In 2013 (Tab. I), the containerized stock was planted in the autumn of 2012 and the bare-rooted stock in the spring of 2013. In the spring of 2013, drought spells did not occur and a precipitation deficit was recorded in the summer period (namely in July). At the end of the 2013 growing season, the containerized planting stock exhibited significantly larger increments than the bare-rooted planting stock as well as much lower post-planting losses on all tested sites. In the autumn of 2016, the losses increased both in the containerized and bare-rooted planting stocks; however, the loss of bare-rooted stock was considerably higher and the increment of containerized planting stock was significantly greater. This indicates that the drought spells in 2015 and 2016 affected the bare-rooted planting stock more than the containerized planting stock.

Although the stock outplanted in 2014 (Tab. I) was growing with no serious problems in 2014 (similarly as the stock outplanted in 2016, i.e. the containerized stock exhibited nearly at all times a greater increment or differences in increments were not significant; a similar trend was recorded in losses, too), the extreme drought in 2015 and the drought in 2016 essentially affected the further growth.

- The drought in 2015 resulted in operationally unacceptable losses on forest regeneration. In general, the losses were higher in the containerized planting stock as compared with the bare-rooted planting stock.

- The following spells of drought in 2016 induced a further increase in the losses, which in some cases reached up to $100 \%$ and were higher in the containerized planting stock of all tree species (with the exception of several Douglas fir plantations) than in the bare-rooted planting stock.

- The above-ground part increment showed a similar trend as the losses. According to increments (and other parameters and features of vitality) recorded in 2016, we can state without any doubt that all plants are still in a deep shock and the containerized plants of all tree species have considerably and significantly smaller increments than the bare-rooted plants.

The stock outplanted in 2015 (Tab. II) was affected by severe drought spells throughout the whole year and the fact showed in massive losses (generally higher than in the stock outplanted in 2014), which were for the most part greater in the containerized planting stock. The increment of containerized planting stock was very small in this year and significantly smaller than the increment of bare-rooted planting stock (increments of both the bare-rooted and containerized planting stocks were very small as compared with the standard planting in 2013-smaller than a half). The following drought spell in 2016 further deepened the losses in all tree species. If the bare-rooted planting stock exhibited higher losses on some sites in the spring of 2016, in the autumn of the same year, the losses of containerized planting stock were higher on a majority of plots than in the bare-rooted planting stock. At that time, the surviving containerized planting stock showed also significantly smaller increments as compared with the bare-rooted planting stock.

Both the bare-rooted and the containerized stock of all tree species planted in 2016 (Tab. II) exhibited very acceptable post-planting losses, which did not exceed (with a single exception) 5\%. At the end of growing season, the losses were higher due to drought in the vegetation period (spring was favourable in terms of moisture) but remained within acceptable limits-ca. up to $15 \%$. Although some partial differences were observed, losses at the end of the growing season were smaller in the containerized planting stock than in the bare-rooted planting stock. On a majority of research plots, all monitored tree species in containers featured significantly greater terminal increments (in spite of being smaller at planting) than the bare-rooted plants, this indicating that the containerized planting stock performed better than the bare-rooted planting stock.

\section{Aggregate evaluation of planting in the period from 2013-2016}

- If the containerized stock is exposed to relatively standard weather conditions after planting, it grows better and has lower losses than the bare-rooted planting stock (planting in 2013-all results, planting in 2014-results in 2014 and planting 2016-results in the spring period of 2016). Difference between the amount of moisture in the spring and during the growing season shows so that less (but still acceptable amount of) moisture in the spring induces higher losses in the bare-rooted than in the containerized planting stock. Shorter spells of drought in the growing season generally reduce the size of shoot increment (comparison of plantations from 2013 and 2014), this showing more in the bare-rooted planting stock than in the containerized planting stock.

- If there are severe drought spells right after planting, both the containerized and bare-rooted stocks exhibit high mortality. Losses are often considerably greater in the containerized planting 
I: Losses and terminal increments (arithmetic mean/standard deviation)-planting in 2013 and 2014

\begin{tabular}{|c|c|c|c|c|c|c|c|c|c|c|c|}
\hline \multirow{3}{*}{ GFT } & \multirow{3}{*}{ Species } & \multirow{3}{*}{ 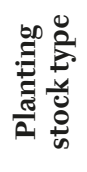 } & \multicolumn{4}{|c|}{ Planting in 2013} & \multicolumn{5}{|c|}{ Planting in 2014} \\
\hline & & & \multicolumn{2}{|c|}{ Increment (cm) } & \multicolumn{2}{|c|}{ Losses (\%) } & \multicolumn{2}{|c|}{ Increment (cm) } & \multicolumn{3}{|c|}{ Losses (\%) } \\
\hline & & & 2013 & 2016 & $\begin{array}{l}\text { Oct. } \\
2013\end{array}$ & $\begin{array}{l}\text { Oct. } \\
2016\end{array}$ & 2014 & 2016 & $\begin{array}{l}\text { Oct. } \\
2014\end{array}$ & $\begin{array}{l}\text { May } \\
2016\end{array}$ & $\begin{array}{l}\text { Oct. } \\
2016\end{array}$ \\
\hline \multirow{6}{*}{$2 \mathrm{~K}$} & \multirow{2}{*}{ SM } & KK & $16.7 / 5.3$ & $35.2 / 12.7$ & 5 & 9 & $15.2 / 3.6$ & $27.0 / 9.4$ & 7 & 11 & 53 \\
\hline & & PK & $7.8 / 4.4^{+}$ & $27.1 / 10.4^{+}$ & 19 & 31 & $9.8 / 3.1^{+}$ & $25.4 / 10.2^{-}$ & 9 & 17 & 34 \\
\hline & \multirow{2}{*}{ BK } & KK & $14.6 / 3.9$ & $37.3 / 10.8$ & 8 & 13 & $8.7 / 3.7$ & $36.8 / 10.4$ & 3 & 36 & 68 \\
\hline & & $\mathrm{PK}$ & $6.6 / 3.2^{+}$ & $31.1 / 10.3^{+}$ & 27 & 41 & $5.2 / 2.1^{+}$ & $41.9 / 14.1^{+}$ & 12 & 35 & 43 \\
\hline & \multirow{2}{*}{ DG } & KK & \multicolumn{4}{|c|}{ Not determined } & $28.2 / 7.7$ & $11.7 / 3.9$ & 5 & 61 & 75 \\
\hline & & PK & \multicolumn{4}{|c|}{ Not determined } & $43.9 / 15.7$ & $10.5 / 4.2$ & 12 & 74 & 90 \\
\hline \multirow{6}{*}{$2 S$} & \multirow{2}{*}{ SM } & KK & $13.3 / 4.8$ & $37.7 / 12.7$ & 13 & 19 & $13.3 / 4.6$ & $22.1 / 8.4$ & 7 & 13 & 56 \\
\hline & & PK & $8.4 / 4.1^{\top}$ & $29.4 / 11.5^{\top}$ & 19 & 31 & $7.7 / 3.2$ & $29.0 / 10.3^{\top}$ & 2 & 4 & 11 \\
\hline & \multirow{2}{*}{ BK } & KK & $15.6 / 5.9$ & $33.3 / 10.3$ & 9 & 17 & $9.9 / 3.3+$ & $35.1 / 12.7+$ & 6 & 58 & 71 \\
\hline & & PK & $8.4 / 3.3^{+}$ & $25.1 / 10.1^{+}$ & 18 & 26 & $6.3 / 2.5$ & $40.3 / 14.9$ & 15 & 39 & 65 \\
\hline & \multirow{2}{*}{ DG } & KK & \multicolumn{4}{|c|}{ Not determined } & $14.4 / 4.8$ & 26.9/8.1 & 5 & 34 & 85 \\
\hline & & PK & & Not determinec & & & $8.7 / 3.1^{+}$ & $25.2 / 7.7$ & 21 & 71 & 91 \\
\hline & SM & KK & $11.7 / 5.1_{+}$ & 29.9/12.7 & 16 & 23 & $12.7 / 4.2$ & $26.6 / 10.4$ & 11 & 33 & 40 \\
\hline & SIVI & PK & $5.5 / 3.2^{+}$ & $22.2 / 13.1^{+}$ & 31 & 43 & $10.6 / 3.6^{\top}$ & $36.4 / 12.6^{+}$ & 3 & 14 & 17 \\
\hline $3 \mathrm{M}$ & BK & KK & $12.2 / 5.3$ & $26.4 / 13.3$ & 6 & 14 & $9.3 / 3.7$ & $13.5 / 5.3$ & 16 & 76 & 77 \\
\hline Jiv1 & DN & PK & $7.4 / 4.1$ & $19.8 / 8.6$ & 19 & 32 & $8.6 / 4.1$ & $18.4 / 6.2$ & 5 & 37 & 61 \\
\hline & $D G$ & KK & & Not determinec & & & $9.8 / 3.9+$ & $14.9 / 7.1_{+}$ & 11 & 56 & 61 \\
\hline & DG & PK & & Not determinec & & & $7.7 / 4.6$ & $43.7 / 17.7$ & 17 & 33 & 38 \\
\hline & & KK & $21.4 / 7.7$ & $42.4 / 16.3$ & 3 & 4 & $10.3 / 3.1$ & $14.1 / 5.2$ & 3 & 40 & 43 \\
\hline & SIM & PK & $12.1 / 3.3^{+}$ & $31.3 / 8.7^{+}$ & 12 & 21 & $6.2 / 2.7^{+}$ & $15.1 / 5.9^{-}$ & 19 & 50 & 55 \\
\hline $3 \mathrm{~K}$ & BK & KK & $23.7 / 8.1$ & $38.7 / 14.4$ & 2 & 7 & $7.4 / 3.3$ & $0.9 / 1.1_{+}$ & 17 & 80 & 100 \\
\hline 3K & BK & $\mathrm{PK}$ & $12.6 / 4.5^{+}$ & $29.3 / 12.1^{+}$ & 11 & 26 & $6.2 / 4.1$ & $9.1 / 3.8^{+}$ & 10 & 53 & 59 \\
\hline & $\mathrm{DC}$ & KK & $22.7 / 10.6$ & $42.4 / 14.7$ & 5 & 7 & $9.3 / 3.9$ & $8.1 / 3.9$ & 12 & 53 & 59 \\
\hline & DG & PK & $16.5 / 10.0$ & $36.2 / 9.8^{\top}$ & 24 & 33 & $8.6 / 2.7$ & $20.7 / 8.2^{\top}$ & 4 & 44 & 44 \\
\hline & SM & KK & $17.3 / 6.4$ & $30.3 / 12.7$ & 6 & 11 & $13.2 / 5.1_{+}$ & $20.9 / 7.1_{+}$ & 1 & 3 & 5 \\
\hline & SIVI & PK & $8.6 / 2.5^{\top}$ & $22.7 / 10.4^{\top}$ & 27 & 36 & $8.4 / 5.2^{\top}$ & $24.3 / 5.4^{\top}$ & 0 & 7 & 10 \\
\hline 35 & BK & KK & $18.1 / 7.1_{+}$ & $34.8 / 10.3+$ & 9 & 17 & $9.3 / 3.4_{+}$ & $22.7 / 9.2+$ & 0 & 21 & 24 \\
\hline נ3 & DK & PK & $10.4 / 3.3^{\top}$ & $26.4 / 8.8^{\top}$ & 22 & 38 & $8.1 / 3.2^{\top}$ & $30.3 / 12.1^{\top}$ & 1 & 15 & 18 \\
\hline & DG & KK & & Not determinec & & & 15.3/7.1_ & $19.9 / 6.4$ & 3 & 12 & 15 \\
\hline & DG & PK & & Not determinec & & & $14.7 / 8.2$ & $23.1 / 7.3^{+}$ & 4 & 12 & 20 \\
\hline & SM & KK & $18.4 / 5.4$ & $37.3 / 14.4_{+}$ & 1 & 6 & $12.7 / 4.4$ & $14.4 / 5.5$ & 0 & 7 & 8 \\
\hline & SIVI & PK & $7.9 / 2.7^{+}$ & $26.1 / 11.7^{\dagger}$ & 23 & 42 & $7.7 / 3.6^{+}$ & $15.9 / 3.9^{+}$ & 0 & 9 & 10 \\
\hline $4 \mathrm{~K}$ & BK & KK & 19.3/7.7 & $31.9 / 12.3$ & 8 & 11 & $9.2 / 4.1$ & $21.9 / 6.9$ & 3 & 12 & 27 \\
\hline $4 \mathrm{~K}$ & DN & PK & $12.5 / 6.2$ & $24.8 / 8.7$ & 20 & 29 & $7.3 / 3.6$ & $24.5 / 5.5$ & 3 & 17 & 21 \\
\hline & $D G$ & KK & $26.4 / 12.1_{+}$ & $43.3 / 11.9_{+}$ & 6 & 12 & $12.6 / 5.2_{+}$ & $18.3 / 6.2_{+}$ & 1 & 5 & 7 \\
\hline & DG & PK & $14.3 / 5.2$ & $32.7 / 12.6$ & 32 & 42 & $10.4 / 6.6$ & $29.2 / 7.7$ & 0 & 8 & 10 \\
\hline & SM & KK & $17.7 / 6.3_{+}$ & $28.8 / 9.9+$ & 7 & 8 & $11.9 / 7.2_{+}$ & $22.2 / 5.8_{+}$ & 2 & 7 & 10 \\
\hline & & PK & $12.2 / 4.1^{+}$ & $23.5 / 8.5^{+}$ & 14 & 19 & $8.6 / 5.1^{+}$ & $34.6 / 11.2^{+}$ & 0 & 3 & 4 \\
\hline $4 \mathrm{~S}$ & BK & KK & $16.9 / 7.3$ & $31.3 / 11.3$ & 7 & 12 & $12.8 / 4.1$ & $20.5 / 7.3$ & 4 & 51 & 63 \\
\hline 4S & BK & PK & $17.1 / 5.7^{-}$ & $25.4 / 8.7^{+}$ & 12 & 23 & $11.2 / 3.6$ & $33.3 / 8.8^{+}$ & 2 & 12 & 19 \\
\hline & $D G$ & KK & $22.3 / 10.4$ & $48.9 / 14.7$ & 5 & 9 & $14.9 / 3.4$ & $27.8 / 9.1_{+}$ & 3 & 17 & 56 \\
\hline & DG & PK & $18.7 / 8.8$ & $39.7 / 13.5$ & 18 & 27 & $10.3 / 3.7^{\top}$ & $35.5 / 10.2^{\top}$ & 5 & 11 & 18 \\
\hline $\begin{array}{l}\text { GFT } \\
\text { BK- } \\
\text { KK - } \\
{ }^{+}{ }^{+}-\end{array}$ & $\begin{array}{l}\text { - group } \\
\text { Europea } \\
\text { containe } \\
\text { statistica }\end{array}$ & $\begin{array}{l}\text { rest ty } \\
\text { eech } \\
\text { ed pla } \\
\text { ignifi }\end{array}$ & $\begin{array}{l}\text { ting stock } \\
\text { ant differer }\end{array}$ & ial and Metho & & & $\begin{array}{l}\text { SM - Norv } \\
\text { DG - Dou } \\
\text { PK - bare- - } \\
\text { "-“ statisti }\end{array}$ & $\begin{array}{l}\text { oruce } \\
\text { ed planting } \\
\text { non-signifi }\end{array}$ & $\begin{array}{l}\text { ck } \\
\text { tt di }\end{array}$ & nce & \\
\hline
\end{tabular}


II: Losses and terminal increments (arithmetic mean/standard deviation) - planting in 2015 and 2016

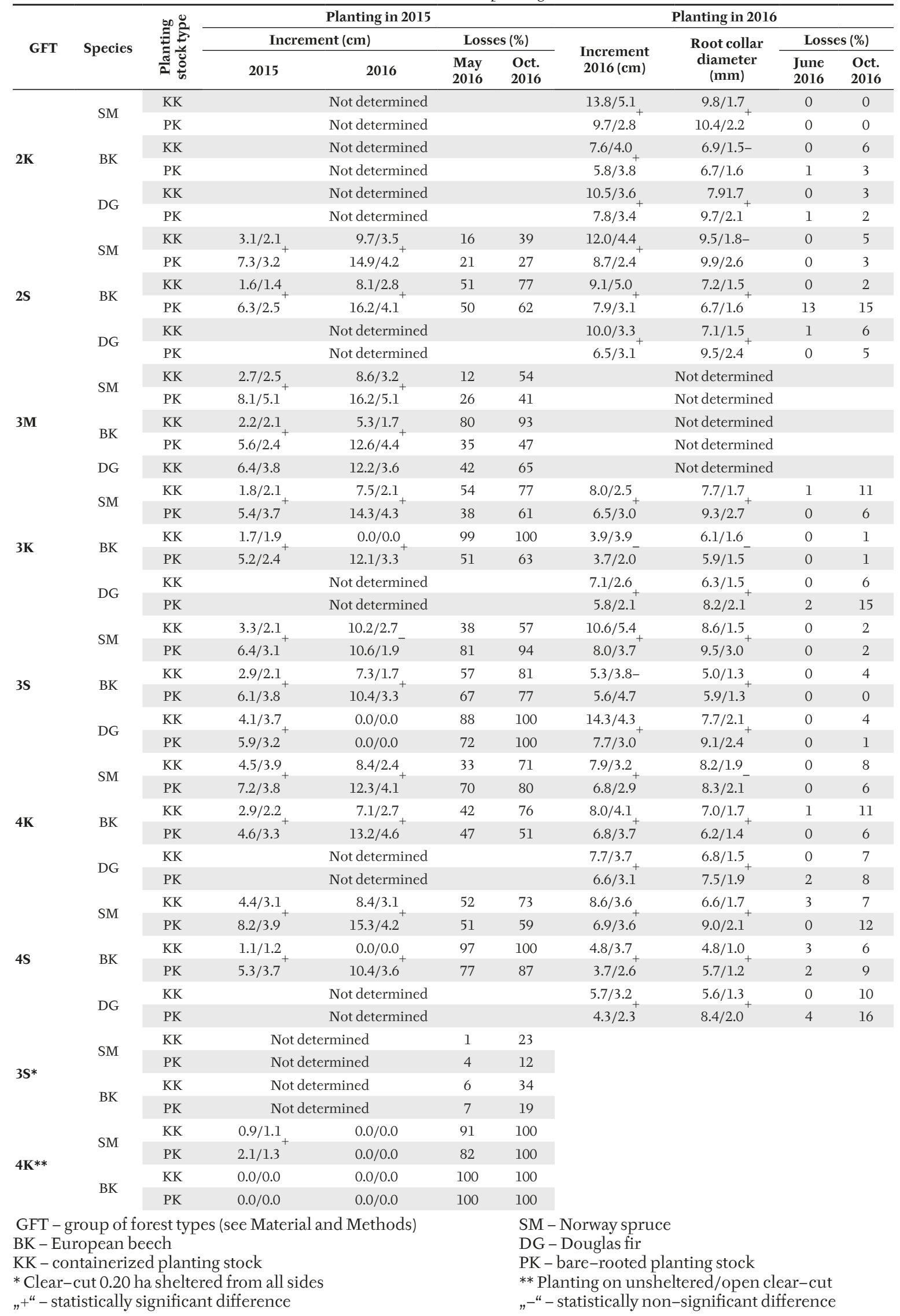


stock than in the bare-rooted planting stock (results of plantations from 2015).

- Recurrent severe droughts further increase the losses in both types of planting stock with losses in both types of planting stock being considerably higher if the drought occurs in the year of planting and in the year coming after the planting (plantations from 2015) as compared with the occurrence of drought spells only in the second or third year after planting (plantations from 2014). Recurrent droughts show more adversely in the containerized planting stock than in the bare-rooted planting stock. Recurrent droughts show negatively even four years after planting (plantation from 2013).

\section{Loss of water from the root ball after simulated drought}

Conclusions derived from Tab. III are as follows:

- On heavier wet soils (4G), root balls lose water slower than on lighter soils (4K).

- Covered root balls lose water slower than uncovered root balls.

- Small root balls (HIKO V-265) lose water considerably faster than large root balls (HIKO V-350).

- Drought lasting 10 days would induce in the small root balls HIKO V-265 water content reduction unacceptable for the growth of plants on both sites without root ball coverage.

- After 20 days of drought, the small root balls (HIKO V-265) on both sites with and without root ball coverage would not have nearly any water content.

- After 30 days of drought, a small water reserve (ca. 20\%) keep only large root balls with root ball coverage.

- The rate of water loss from the balls could have been even greater because the balls were "planted" without plants and physiological processes of plants did not withdraw water.

\section{Influence of root ball size and morphological parameters of above-ground part on drought stress}

Tab. IV indicates that the larger is the root ball, the lesser are the post-planting losses and the higher are the shoot and root collar increments; the differences recorded in the extreme year of 2015 are highly significant. Tabs I and II point indirectly to the same fact that on the same site and in different years of planting, plants with larger root balls exhibited lower losses than plants with smaller root balls; nearly at all times, spruce saplings raised in HIKO V 350 containers suffered lower losses than beech saplings raised in HIKO V 265 containers.

III: Weight loss of root ball (in \%) after simulated drought (at the beginning of testing, soil moisture content on GFT 4K and GFT 4G was $60 \%$ and $70 \%$, respectively)

\begin{tabular}{|c|c|c|c|c|c|c|}
\hline \multirow{2}{*}{$\begin{array}{l}\text { Days of } \\
\text { drought }\end{array}$} & \multicolumn{4}{|c|}{ GFT $4 K$} & \multicolumn{2}{|c|}{ GFT 4G } \\
\hline & \multicolumn{2}{|c|}{ Covered root ball } & \multicolumn{2}{|c|}{ Uncovered root ball } & $\begin{array}{c}\begin{array}{c}\text { Covered root } \\
\text { ball }\end{array} \\
\text { HIKO } \\
\text { V-350 }\end{array}$ & $\begin{array}{c}\text { Uncovered } \\
\text { root ball } \\
\text { HIKO } \\
\text { V-265 }\end{array}$ \\
\hline 0 & 100 & 100 & 100 & 100 & 100 & 100 \\
\hline 15 & 83 & 57 & 64 & 30 & 73 & 42 \\
\hline 20 & 61 & 44 & 52 & 30 & 66 & 31 \\
\hline 30 & 50 & 33 & 41 & 30 & 51 & 30 \\
\hline
\end{tabular}

GFT-group of forest types (see Material and Methods)

IV: Influence of root ball size on the growth of BK (beech) fvI and losses 1 year after planting (same seed, same substrate, same method of growing, containers HIKO V 120, HIKO V 265, HIKO V 350, planting in 2015)

\begin{tabular}{|c|c|c|c|c|c|c|}
\hline \multirow[b]{2}{*}{ GFT } & \multirow{2}{*}{$\begin{array}{c}\text { Root ball size } \\
\qquad\left(\mathrm{cm}^{3}\right)\end{array}$} & \multicolumn{2}{|c|}{ Shoot height (cm) } & \multicolumn{2}{|c|}{ Root collar diameter (mm) } & \multirow{2}{*}{$\begin{array}{c}\text { Losses } 2015 \\
(\%)\end{array}$} \\
\hline & & $\begin{array}{l}\text { At the time of } \\
\text { planting }\end{array}$ & $\begin{array}{c}\text { After one } \\
\text { growing season }\end{array}$ & $\begin{array}{c}\text { At the time of } \\
\text { planting }\end{array}$ & $\begin{array}{c}\text { After one } \\
\text { growing season }\end{array}$ & \\
\hline \multirow[t]{2}{*}{$3 \mathbf{K}$} & 265 & $35.2 \pm 1.5$ & $39.5 \pm 1.7$ & $3.7 \pm 0.6$ & $4.2 \pm 0.7$ & 61 \\
\hline & 350 & $45.8 \pm 1.6$ & $53.4 \pm 5.1$ & $4.5 \pm 0.4$ & $6.4 \pm 0.9$ & 21 \\
\hline \multirow[t]{2}{*}{$4 S$} & 265 & $36.2 \pm 1.6$ & $40.2 \pm 1.9$ & $3.8 \pm 0.4$ & $4.4 \pm 0.8$ & 60 \\
\hline & 350 & $45.1 \pm 1.4$ & $55.2 \pm 5.8$ & $4.4 \pm 0.6$ & $6.6 \pm 1.2$ & 14 \\
\hline
\end{tabular}

GFT-group of forest types (see Material and Methods) 
V: Influence of BK (beech) fol root collar diameter at planting on losses 1 year after planting (container HIKO V-265, planting in 2015, identical shoot length at the time of planting)

\begin{tabular}{|c|c|c|}
\hline GFT & Root collar diameter ( $\mathrm{mm}$ ) & Losses $2015(\%)$ \\
\hline \multirow{3}{*}{$3 \mathbf{K}$} & up to 4.0 & 57 \\
\hline & $4.1-5.5$ & 33 \\
\hline & above 5.6 & 21 \\
\hline \multirow{3}{*}{$4 K$} & up to 4.0 & 42 \\
\hline & $4.1-5.5$ & 28 \\
\hline & above 5.6 & 11 \\
\hline
\end{tabular}

GFT-group of forest types (see Material and Methods)

Tab. V documents that plants with a larger root collar diameter showed considerably lower losses than plants of the same height with a smaller root collar diameter even in the planting year of 2015 with extremely low precipitation. The same fact is indirectly shown also in Tab. IV, however, here the plants with a larger root collar diameter had also greater above-ground part height.

\section{Influence of clear-cut area shelter on drought stress}

In 2015, even completely sheltered small clear-cut areas and completely open clear-cut areas were planted. Tab. II clearly shows that the severe drought in 2015 did not affect plantations on the sheltered clear-cuts (up to 0.2 ha) at all; however, a further drought spell in 2016 impacted the plantations even on them-considerably more the containerized planting stock than the bare-rooted planting stock. Nevertheless, the losses were much lower as compared with the plantations on the standard clear-cut areas (up to 1 ha). Planting on the completely unsheltered clear-cuts (ca 4.0 ha) resulted in almost 100\% losses in all species and both types of planting stock already in 2015.

\section{DISCUSSION}

The conclusion following out of our surveys was somewhat unexpected: the containerized planting stock responds to severe, long-lasting and recurrent drought spells in the first two years after planting worse than the bare-rooted planting stock. Reasons are multiple.

The root ball of the containerized planting stock consists mainly of peat, which dries out considerably faster than mineral soil; dried out peat recollects water unwillingly and very slowly (Valtera 2009). All this is intensified when the root ball is not covered with at least $2 \mathrm{~cm}$ of mineral soil at planting, its volume is too small, or it is planted (even only partly) into humus horizons (Czech standard ČSN 48 2116; Szabla and Pabian, 2003).

Dry soil draws water from the root system (Mauer et al. 2009). Nilsson, Orlander (1995) mention a low soil water potential especially in Year 2 and Year 3 after the establishment of clear-cut area. In the containerized planting stock, a larger part of fine roots occur closely under the root ball surface and having been planted in dry soil, plants suffer already when the thin surface layer of the root ball loses water (Jurásek, Martincová, Leugner 2010).

Although the containerized planting stock exhibits minimal losses right after planting and accrues favourably, only a small part of roots grow from the root ball into the mineral soil (Novák 2017; Macek 2017). This may be worsened by the formation of smoothed walls of air pockets at planting (Jurásek et al., 2011), the plant still living more or less from the conditions and the environment of the root ball. Unlike in the bare-rooted planting stock, it may not be rooted properly and a further stress affecting namely the root system weakens the containerized planting stock more than the bare-rooted planting stock.

Inhibition of roots growing out from the root ball is further supported by the great chemical difference between the root ball composition and the composition of surrounding soil (Mauer et al., 2009).

Together with the large root system, another factor of planting stock quality (and hence forest regeneration success) is the diameter of its root collar (Czech standard ČSN 48 2115). The used containerized planting stock (containerized seedlings in particular) had at all times a lower diameter than the bare-rooted planting stock. This fact, too, affected results at the time of drought spells, especially in the first year after planting.

Even though the research results indicate that the small, completely sheltered clear-cut area are the best for planting, this fact, too, has its limitations. For example, Souchová (2017), who conducted research in the same region and in the same stands with planting BK fvl on small and sheltered clear-cuts and under stands of 0.5 in density, informs that the underplanting was the worst option because the underplanted stands were a too strong competitor in fighting for water for small and poorly rooted containerized beeches.

It also followed out from the surveys that plants with a large root ball grew better (can retain moisture longer). This is a relatively well-known fact since for example many foresters after their experience in the practice wish (require) only a containerized planting stock with large root balls 
and reject low-volume seedlings. For the same reason, the largest forest nursery operations in Austria give up raising small-volume containerized seedlings and continue growing only larger-volume containerized transplants. As a limit for the survival of containerized plants, Helenius et al. (2005) state $7 \%$ of water content in the balls; according to them however, the growth of plants is affected already when the root ball water content is $20 \%$ and lower.

It should be also pointed out that before and after planting, the plant is affected by a number of other negative factors, which may increase losses and retard the growth (fungal pathogens, insect pests, inadequate handling with the planting stock before planting etc.) and the impact of which may be multiplied (Leugner et al. 2012).

This research was primarily not conducted (with the exception of year 2017) as a testing of the influence of drought periods on the young plantations of bare-rooted and containerized planting stock. All plantations were established to monitor the growth of bare-rooted and containerized planting stock on the most representative sites of mid-and lower elevations. The reason for this research was the extreme course of weather.

\section{CONCLUSION}

Main conclusions derived from our monitoring of the growth of bare-rooted and containerized planting stock of European beech, Norway spruce and Douglas fir on the most representative sites (GFT 2K, 2S, 3M, 3K, 3S, 4K, 4S) in mid-and lower elevation of the Czech Republic after severe spells of drought induced by abnormal weather course in the period 2012-2016 are as follows:

If the spring planting is followed by normal weather, the containerized planting stock grows better than the bare-rooted planting stock.

If there are severe droughts after planting, both the bare-rooted and the containerized planting stock suffer significant mortality, the containerized planting stock exhibiting higher losses. Recurrent drought spells are responded to more sensitively by the containerized planting stock.

Severe droughts induce unacceptable operating losses in the containerized planting stock at all times; recurrent spells of drought in particular may result in a $100 \%$ loss.

Drought spells are always better sustained by the containerized planting stock with a large root ball, with root ball coverage and a large-diameter root collar.

The success of forest regeneration on clear-cut areas is significantly affected by the clear-cut area shelter, by the type of planting stock and occurring spells of drought. If the clear-cut areas are small (up to about $0.20 \mathrm{ha}$ ) and sheltered by adult forest stands from all sides, post-planting losses following one or more drought spells are considerably smaller than if the planting was made on the standard clear-cut area (up to 1 ha). If planted out onto a large unsheltered clear-felled area, the containerized stock exhibits very high losses already in the first year; after recurrent drought periods, the losses reach $100 \%$.

No essential differences were recorded in the growth of bare-rooted or containerized planting stock or in the tested tree species in relation to the used groups of forest types (even though it was not clearly demonstrated, the most sensitive to droughts is Douglas fir).

Favourable growth in the first year after planting does not guarantee the success of the forest regeneration, namely in the containerized planting stock.

Alsoin relation to spring droughtspells occurring relativelymorefrequently, itseems that the containerized stock should be planted in the autumn for greater success and certainty. The current procedures of applying and planting the containerized stock may apparently fail in the period of long lasting and recurrent drought spells. Possible solutions can be seen in the use of hydrogels added into the root ball or hole at planting, or even a change of technology of raising the containerized planting stock.

Acknowledgement

The paper was financially supported from the project KUS QJ 1520080 "Optimization of artificial forest regeneration in the Czech Republic".

\section{REFERENCES}

BAGAR, R. and NEKOVÁŘ, J. 2006. Vegetation development tendency in Bílé Karpaty and Vizovické vrchy natural forest region. In: Fyziologická odezva proménlivosti podnebí. Česká bioklimatologická společnost and Český hydrometeorologický ústav.

BOLTE,A., CZAJKOWSKI, T., COCOZZA, C., TOGNETTI, R.,DE MIGUEL, M.,PSIDOVA, E., DITMAROVA, L., DINCA, L., DELZON, S., COCHARD, H., RAEBILD, A., DE LUIS, M., CVJETKOVIC, B., HEIRI, C. and MÜLLER, J. 2016. Desiccation and Mortality Dynamics in Seedlings of Different European Beech (Fagus sylvatica L.) Populations under Extreme Drought Conditions. Frontiers in Plant Science, 7:751. 
CHMI. 2017. Úvod do problému klimatické zmèny. Český hydrometeorologický ústav. [Online]. Available at: http://portal.chmi.cz/files/portal/docs/meteo/ok/klimazmena/files/cc_chap0l.pdf [Accessed: 2017, November 15].

DUŠEK, V. 1997. Lesni školkařství. 1st Edition. Písek: Matice lesnická.

HELENIUS, P., LUORANEN, J. and RIKALA, R. 2005. Effect of preplanting drought on survival, growth and xylem water potential of actively growing Picea abies container seedlings. Scandinavian Journal of Forest Research, 20(2): 103-109.

JURÁSEK, A., MARTINCOVÁ, J. and NÁROVCOVÁ, J. 2004. Problematika použití krytokořenného sadebního materiálu z intenzívních školkařských technologií v podmínkách ČR. In: Možnosti použití sadebního materiálu z intenzívních školkařských technologií pro obnovu lesa. Workshop proceedings. 3-4 June 2004, Opočno. Lesnická práce, pp. 6-15.

JURÁSEK, A., MARTINCOVÁ, J. and LEUGNER, J. 2010. Manipulace se sadebním materiálem lesních dřevin od vyzvednutíve školce ažpo výsadbu. Certificated Methodics. Forestry and Game Management Research Institute.

JURÁSEK, A. ha 2011. Zásady manipulace se sadebním materiálem lesních dřevin od vyzvednutí až po jeho výsadbu při obnově lesa. In: Doprava, manipulace a sázení sadebního materiálu lesních ḋ̌evin. Workshop proceedings. 18 August, Řečany nad Labem, pp. 4-14.

LEUGNER, J., MARTINCOVÁ, J. and JURÁSEK, A. 2012. Vliv vysychání během manipulace a prostředí po výsadbě na růst sazenic smrku ztepilého (Picea abies (L.) Karst.). Zprávy lesnického výzkumu, 57(1): 1-7.

JOUKLOVÁ, E. 2016. Smrky na severní Moravě a v jižním Polsku odumírají. Lesníci hledají řešení. Les aktuálně. [Online]. Available at: http//www.lesaktualne.cz/lesnictvi/smrky-na-severni-morave-a-v-jiznimpolsku-odumiraji-lesnici-hledaji-reseni/more-6465. [Accessed: 2017, November 15].

MACEK, J. 2017. Vliv zpiosobui sadby krytokořenného sadebního materiálu smrku ztepilého a buku lesního na odrüstání kultur a vývin jejich kořenového systému. Thesis. Mendel university in Brno.

MAUER, O. and PALÁTOVÁ, E. 2006. Forest tree species root system condition in dependence on the changing climate. In: Fenologická odezva promènlivosti podnebí. Proceedings. Ptaha: Česká bioklimatologická společnost and CHMI, pp. 42-50.

MAUER, O. ha 2009. Zakládání lesů II. University Mimeographed. Brno: Mendel University in Brno.

MAUER, O. and MAUEROVÁ, P. 2010. Vliv kvality užitého sadebního materiálu na následnou kvalitu a stabilitu založených kultur. In: Aktuálne problémy lesného škôlkarstva, semenárstva a umelej obnovy lesa. Zvolen: Národné lesnické centrum, pp.117-122.

MAUER, O. and VANĚK, P. 2013. Pěstování sadebního materiálu pro podsadby, do mrazových a suchých lokalit. In.: Lesné semenárstvo, škôllkarstvo a umelá obnova lesa. Združenie lesných škôlkarov Slovenskej republiky, 12-13 June. Snina:Združenie lesných škôlkarov Slovenskej republiky, pp. 1-5.

MAUER, O. and VANĚK, P. 2013. Vliv biotechniky sadby krytokořenného sadebního materiálu na kvalitu a stabilitu založených lesních porostů. In: Aktuálne problémy v zakladaní a pestovaní lesa. 1st Edition. Zvolen: Národné lesnícke centrum, pp. 38-45.

NOVÁK, J. 2017. Ruistkulturzaložených rozdílnými biotechnikami sadby krytokořenného sadebního materiálu. Bachelors Thesis. Brno: Mendel university in Brno.

PLÍVA, K. 1991. Funkčné integrovanélesníhospodáriství 1. Přirodní podmínky v lesním plánování. Brandýs nad Labem: Ústav pro hospodářskou úpravu lesů.

POLENO, Z., VACEK, S. ha 2009. Péstovánílesio. Prakticképostupy pěstovánílesio. 3rd Edition. Lesnická práce.

ROŽNOVSKÝ, J. and BAUER, Z. 2006. Dynamics of phenological of flowering of selected woody species. In.: Fyziologická odezva proménlivosti podnebí. Česká bioklimatologická společnost and Český hydrometeorologický ústav.

SOUCHOVÁ, J. 2017. Rekonstrukce prípravných porosti̊ břizy bèlokorépodsadbami. Bachelors Thesis. Brno: Mendel university in Brno.

SZABLA, K. and PABIAN, R. 2003. Szkółkarstwo kontenerowe. Nowe technologie i techniki w szkótkarstwie leśnym. Warszawa: CILP.

SZABLA, K. and PABIAN, R. 2009: Szkolkarstwo kontenerowe. Lasy panstwowe.

ŠMELKOVÁ, L. ha 2001. Lesné školky. Zvolen: Ústav pro výchovu a vzdelávanie pracovníkov LVH SROV.

ÚŘAD PRO TECHNICKOU NORMALIZACI, METROLOGII A STÁTNÍ ZKUŠEBNICTVÍ. 2012. Forest reproductive material. ČSN 48 2115. Czech standard. Praha: Úřad pro technickou normalizaci, metrologii a státní zkušebnictví.

ÚŘAD PRO TECHNICKOU NORMALIZACI, METROLOGII A STÁTNÍ ZKUŠEBNICTVÍ. 2015. Artificial reforestation and afforestation. ČSN 48 2116. Czech standard. Praha: Úřad pro technickou normalizaci, metrologii a státní zkušebnictví.

VALTERA, J. 2009. Půdní substráty, komposty, zeminy, hydroponické roztoky. In: Zvyšování kvalifikačních znalostí a dovednostítechnických pracovníkư v oboru lesního školkaŕtví. Tribun EU and Mendel University in Brno, pp. 292-301.

VIEWEGH J., KUSBACH A. and MIKESKA M. 2003: Czech forest ecosystem classification. Journal of Forest Science, 49(2): 85-93. 
omauer@mendelu.cz

Contact information rozmanek@lescus.cz

katerina.houskova@mendelu.cz 